\title{
PENGARUH SOCIAL COMPARISON PADA WORK ATTITUDE: PERAN PEMODERASIAN COMPETITIVE WORK GROUP
}

\author{
Nuri Herachwati ${ }^{1}$, Jovi Sulistiawan ${ }^{2}$, Mario Gonzales Belando Nguru ${ }^{3}$ \\ Departemen Manajemen Fakultas Ekonomi dan Bisnis, Universitas AirlanggaSurabaya \\ e-mail: mario.gonzales.belando@gmail.com
}

\begin{abstract}
This study originated from a survey conducted by JobStreet Indonesia against its members. The result is surprising, that more than 70\% of employees of companies in Indonesia do not have a clear career path. This study aims to assess how much influence of social comparison to career satisfaction, organizational commitment, and turnover intention. Then, in this study also use variable competitive work group as a moderator variable that can strengthen or weaken the effect between variables. The sample that used in this study was 127 permanent employees of PT Indofood Sukses Makmur Tbk Bogasari Flour Mills Division Surabaya. This study used analysis techniques Partial Least Square (PLS). Based on the research results, it is evident that downward social comparison has significant effect on career satisfaction, upward social comparison has significant effect on turnover intention, career satisfaction also significantly influence organizational commitment, and organizational commitment has significant effect on turnover intention. While the influence of upward social comparison to career satisfaction, career satisfaction and turnover intention against downward social comparison to the turnover intention is not significant, and there is no moderating effect on the competitiveness work group on the relationship between social comparison with career satisfaction and upward social comparison with turnover intention and there is a moderating effect on the competitiveness work group on the relationship between the downward social comparison with turnover intention.
\end{abstract}

Keywords: upward and downward social comparison, career satisfaction, organizational commitment, turnover intention, competitive work group.

\begin{abstract}
Abstrak
Penelitian ini berawal dari hasil survey yang dilakukan oleh JobStreet Indonesia terhadap anggotanya. Hasil survey tersebutmenyatakanbahwa sebanyak lebih dari $70 \%$ karyawan perusahaan di Indonesia tidak memiliki kejelasan jenjang karir. Penelitian ini bertujuan untuk mengkaji seberapa besar pengaruh social comparison terhadap career satisfaction, organizational commitment, dan turnover intention. Kemudian, dalam penelitian ini juga digunakan variabel competitive work group sebagai variabel moderator yang dapat memperkuat atau memperlemah pengaruh antar variabel. Sampel yang digunakan dalam penelitian ini adalah 127 karyawan tetap PT Indofood Sukses Makmur Tbk Bogasari Flour Mills Division Surabaya. Penelitian ini menggunakan teknik analisis Partial Least Square (PLS). Berdasarkan hasil penelitian, terbukti bahwa downward social comparison berpengaruhpositif signifikan terhadap career satisfaction, upward social comparison berpengaruh positifsignifikan terhadap turnover intention,career satisfaction juga berpengaruhpositif signifikan terhadap organizational commitment, serta organizational commitment berpengaruh negatifsignifikan terhadap turnover intention. Sedangkan pengaruh upward social comparison terhadap career satisfaction, career satisfaction terhadap turnover intention dan downward social comparison terhadap turnover intention adalah tidak signifikan, serta tidak terdapat efek moderasi dari competitiveness work group pada hubungan antara social comparison dengan career satisfaction dan upward social comparison dengan turnover intention serta terdapat efek moderasi dari competitiveness work group pada hubungan antara downward social comparison dengan turnover intention.
\end{abstract}

Kata kunci: social comparison upward dan downward, career satisfaction, organizational commitment, turnover intention, competitive work group. 


\section{PENDAHULUAN}

Baru-baru ini JobStreet Indonesia, selaku salah satu web pencari kerja, melakukan survei mengenai jenjang karir di perusahaan. Survei ini dilakukan terhadap 13.817 anggotanya dengan $42,7 \%$ responden telah bekerja di perusahaan saat ini selama satu sampai tiga tahun dan $36,6 \%$ bekerja pada posisi junior staff. Berdasarkan survey tersebut, seperti yang dilansir oleh portalHR dalam websitenya, diperoleh hasil yang cukup mengejutkan bahwa $78,3 \%$ responden menyatakan bahwa di perusahaan tempat bekerja saat ini tidak memiliki jenjang karir yang jelas. (http://www.portalhr.com/berita/783-karyawantidak punya-jenjang-karir-yang-jelas/). Melalui survey ini pula diketahui bahwa jenjang karir merupakan faktor penting kedua setelah gaji yang dapat mempengaruhi karyawan untuk pindah ke perusahaan lain. Hasil survey tersebut mengindikasikan bahwa mayoritas perusahaan masih belum menyadari pentingnya karir bagi karyawan dan bagaimana dampaknya terhadap organisasi.

Menurut Heslin (2005), seorang karyawan akan merasa puas dengan karirnya apabila karyawan merasakan adanya pengembangan keahlian baru terhadap dirinya, keseimbangan antara kehidupan dan pekerjaannya, tantangan, serta terpenuhi tujuannya. Karyawan yang puas terhadap karirnya akan memutuskan untuk tetap tinggal di organisasi. Begitu pula sebaliknya, jika karyawan tidak merasa puas dengan karirnya di organisasi yang sekarang, maka akan timbul niat untuk keluar dari organisasi. Selain itu, karyawan yang merasa puas dengan karirnya akan memiliki komitmen terhadap organisasinya. Menurut pernyataan Lee dan Bruvold (2003), karyawan yang merasakan perlakuan lebih baik dari organisasi mengenai pengembangan karirnya, akan menunjukkan kepuasan karir yang kemudian diikuti dengan tingginya level komitmen terhadap organisasi. maka akan mengakibatkan work attitude atau sikap kerja yang positif dari karyawan. Work Attitude atau sikap kerja yang dimaksud adalah terdiri dari kepuasan karir, komitmen organisasional, serta niat untuk keluar dari organisasi (Dyke dan Duxbury, 2011)

Ketidakjelasan jenjang karir di suatu perusahaan akan membuat karyawan cenderung untuk keluar dari organisasi atau perusahaan dan mencari perusahaan yang memiliki jenjang karir yang jelas. Jika perusahaan tidak sadar akan pentingnya jenjang karir atau dukungan perusahaan terhadap karir karyawan maka perusahaan jelas akan mengalami kerugian. Hal ini disebabkan karena jenjang karir merupakan faktor yang mampu untuk mempertahankan best talent atau karyawan terbaik yang ada di perusahaan (Barnett \& Bradley, 2007). Ketika karyawan terbaik meninggalkan organisasi maka perusahaan harus berusaha untuk mencari penggantinya dan hal tersebut cukup memakan waktu dan biaya.

Beberapa penelitian mengemukakan bahwa salah satu hal penting yang mampu untuk memotivasi dan mempertahankan karyawan adalah kepuasan karir karyawan (Barnett dan Bradley, 2007; Kim, Kim, \& Yoo, 2012; Lin \& Chen, 2004. Ketika perusahaan tidak mampu untuk memberikan kepuasan karir bagi karyawan maka karyawan akan cenderung untuk mencari perusahaan lain yang mampu untuk memenuhi kebutuhannya akan pengembangan karir, begitu pula sebaliknya, ketika ada dukungan dari perusahaan maka karyawan akan cenderung untuk tetap tinggal di perusahaan (Lin \& Chen, 2004).

Komitmen karyawan terhadap organisasi bukan hanya berasal dari keterikatan karyawan terhadap organisasi tetapi juga berasal dari komitmen karyawan terhadap karir di dalam organisasi atau perusahaan saat ini. Lin \& Chen (2004) menyatakan bahwa karyawan dengan komitmen organisasional yang rendah akan cenderung untuk meninggalkan organisasi, jika karyawan tersebut memiliki komitmen yang tinggi terhadap karirnya saat ini maka karyawan akan cenderung akan mencari kesempatan lain yang mampu memuaskan kebutuhan mengenai karirnya.

Kepuasan karir seorang karyawan dipengaruhi oleh cara karyawan membandingkan pencapaian karir yang dimilikinya dengan pencapaian karir rekan kerjanya (Eddleston, 2009). Hal tersebut mengacu pada teori perbandingan sosial atau social comparison theory yang pertama kali dikemukakan oleh Festinger pada tahun 1954 (Eddleston, 2009). Berdasarkan teori tersebut, seseorang cenderung untuk membandingkan dirinya dengan orang lain baik yang lebih sukses (upward) ataupun dengan orang yang berada di bawahnya (downward). 
Eddleston (2009) mengemukakan bahwa ketika seseorang cenderung untuk membandingkan dirinya dengan orang yang lebih sukses atau memiliki kinerja yang lebih baik, maka akan cenderung untuk memiliki kepuasan karir yang rendah. Sedangkan ketika seseorang cenderung membandingkan dirinya dengan orang yang tidak lebih suskes dibanding dirinya, maka akan meningkatkan self esteem dan juga kebanggaan terhadap dirinya sehingga akan meningkatkan kepuasan karir. Seseorang yang memiliki kecenderungan untuk melakukan upward comparison atau membandingkan dirinya dengan orang lain yang lebih sukses, akan meningkatkan niat untuk keluar dari organisasi (Eddleston, 2009). Hal ini disebabkan karena seseorang dengan kecenderungan melakukan upward comparison akan mencari pekerjaan lain yang mampu untuk memenuhi kebutuhan yang berupa pengembangan diri.

Selain dari sisi individu, tingkat persaingan dalam kelompok kerja juga disinyalir mampu untuk memperkuat pengaruh antara perbandingan sosial atau social comparison dengan kepuasan karir dan juga niat untuk keluar. Eddleston (2009) menyebutkan bahwa seseorang yang memiliki kecenderungan untuk upward ataupun downward comparison akan membandingkan dirinya dengan orang lain yang ada disekitarnya. Dalam tingkat persaingan kelompok kerja yang tinggi, seseorang yang melakukan upward comparison akan termotivasi dengan orang yang lebih sukses dengan dirinya tetapi merasa iri dengan kesuksesan orang lain sehingga akan menurunkan self esteem, sehingga akan menurunkan kepuasan karirnya dan akan meningkatkan niat untuk keluar dari organisasi.

Salah satu perusahaan Indonesia yang memperhatikan pengembangan karir karyawan adalah PT Indofood Sukses Makmur Tbk Bogasari Flour Mills Division Surabaya. Menurut Bambang Darundriyo, Manajer HR PT Indofood Sukses Makmur Tbk Bogasari Flour Mills Division Surabaya, tidak terdapat diskriminasi dalam kesempatan untuk meraih jenjang karir yang lebih tinggi di Bogasari. Semua level jabatan memiliki hak dan kesempatan yang sama untuk mendapatkan jenjang karir ataupun pengembangan diri di perusahaan. Namun, tetap ada syarat yang harus dipenuhi. Jadi, selama karyawan memenuhi syarat yang telah tertera dalam PKB (Perjanjian Kerja Bersama) dan standar yang diwajibkan oleh perusahaan, semua karyawan memiliki kesempatan yang sama untuk mendapatkan jenjang karir yang lebih tinggi. Pernyataan tersebut sesuai dengan sebuah artikel lain pada www.swa.co.id dimana artikel tersebut memuat hasil wawancara dengan Franky Welirang selaku Direktur Utama PT Indofood Sukses Makmur Tbk yang merupakan induk perusahaan PT Indofood Sukses Makmur Tbk Bogasari Flour Mills Division. Dalam artikel tersebut, beliau menyatakan bahwa terdapat standar career path di dalam perusahaan dan penyesuaian yang jelas di setiap unit level manajemen. Pernyataan tersebut tentu berlaku bagi semua Grup Bisnis PT Indofood Sukses Makmur Tbk. Hal ini menjelaskan bahwa PT Indofood Sukses Makmur Tbk Bogasari Flour Mills Division Surabaya memiliki perhatian khusus dan memberikan dukungan terhadap jenjang karir karyawannya.

Penelitian ini berusaha untuk mengkaji kepuasan karir karyawan PT Indofood Sukses Makmur Tbk Bogasari Flour Mills Division Surabaya terhadap niat untuk keluar dari organisasi ditinjau dari sisi individu melalui perbandingan sosial (social comparison) dan dari sisi kelompok kerja. Di dalam PT Indofood Sukses Makmur Tbk Bogasari Flour Mills Division Surabaya karyawan tidak hanya bekerja secara individu, tetapi juga dengan kelompok sehingga memungkinkan terjadinya persaingan di dalamnya. Maka dari itu, penelitian ini juga berusaha untuk mengetahui efek dari persaingan dalam kelompok kerja.

\section{LANDASAN TEORI DAN PENGEMBANGAN HIPOTESIS}

Eddleston (2009) mengemukakan bahwa manusia cenderung untuk membandingkan dirinya dengan orang lain. Hal ini berdasarkan teori yang dikembangkan oleh Festinger pada tahun 1954, yang disebut dengan teori perbandingan sosial (Eddleston, 2009). Teori perbandingan sosial menyatakan bahwa individu cenderung untuk membandingkan kemampuannya dengan kemampuan orang lain.

Menurut teori perbandingan sosial, terdapat 2 cara seseorang membandingkan dirinya dengan orang lainyaitu:

a. Perbandingan keatas (upward)

Membandingkan dirinya dengan orang yang lebih baik, dari segi kemampuan, 
pengetahuan, karir dan lain sebagainya. Menurut Eddleston (2009), orang dengan kecenderungan upward comparison biasanya memiliki motivasi yang kuat untuk menjadi lebih baik dari sebelumnya.

b. Perbandingan kebawah (downward) Membandingkan dirinya dengan orang yang lebih inferior. Eddleston (2009) mengemukakan bahwa seseorang akan membandingkan dengan orang yang tidak lebih baik dari dirinya dengan tujuan untuk mempertahankan atau menguatkan citra diri yang dimilikinya. Downward comparisons membuat individu merasa lebih nyaman dengan dirinya sendiri dan dengan situasi yang ada saat ini.

Berdasarkan perspektif teori perbandingan sosial, seseorang cenderung akan tidak puas terhadap karirnya ketika terdapat perbedaan antara apa yang diinginkan dengan yang didapatkan. Selain itu, ketidak puasan akan muncul ketika orang lain lebih baik daripada dirinya. Eddleston (2009) mengemukakan bahwa seseorang dengan kecenderungan untuk membandingkan dengan orang lain yang lebih baik maka akan merasa tidak puas dengan apa yang telah dicapainya saat ini. Namun sebaliknya, ketika seseorang cenderung untuk membandingkan dengan orang lain yang lebih inferior, maka hal tersebut akan membuat dirinya/karyawan merasa puas dengan pencapaiarkarirnya.

H1: Perbandingan sosial (a) upward memiliki pengaruh negatif terhadap kepuasan karir, sedangkan (b) downward memiliki pengaruh positif terhadap kepuasan karir.

Capelli (2000) mengemukakan bahwa faktor paling penting bagi karyawan ketika bergabung ataupun bertahan dalam sebuah perusahaan adalah luasnya ruang lingkup untuk pengembangan karir dan peluang untuk tumbuh. Hal inilah yang kemudian akan menentukan apakah karyawan puas dengan karirnya. Ketika perusahaan tidak mampu untuk memberikan kepuasan karir bagi karyawan, maka karyawan cenderung akan mencari perusahaan lain yang mampu untuk memenuhi kebutuhannya akan pengembangan karir. Begitu pula sebaliknya, ketika karyawan mendapatkan dukungan dari perusahaan mengenai pengembangan karirnya, maka karyawan akan cenderung untuk tetap tinggal di perusahaan (Lin \& Chen, 2004).

H2: Kepuasan karir berpengaruh positif terhadap komitmen organisasional

Kepuasan karir merupakan prediktor yang signifikan terhadap keluarnya karyawan dari organisasi. Niat untuk keluar merupakan indikator atau tanda-tanda seseorang akan meninggalkan organisasi. Turnover intention menurut Mobley (1977) didefinisikan sebagai evaluasi mengenai posisi seseorang saat ini yang berhubungan dengan keinginan seseorang untuk keluar dan mencari pekerjaan lain.Ketika seorang karyawan memiliki kepuasan karir yang rendah, maka karyawan tersebut cenderung akan memutuskan untuk keluar dari organisasi (Buchana, 1994; Wright \& Bonett, 2007).

H3: Kepuasan karir berpengaruh negatif terhadap niatuntuk keluar dari organisasi.

Karyawan yang memiliki komitmen terhadap organisasi atau perusahaan cenderung memiliki keinginan untuk keluar yang rendah. Semakin karyawan merasa terikat dengan organisasi, maka semakin tinggi pula keinginan untuk terus menjadi anggota organisasi atau dengan kata lain kecil kemungkinan untuk memiliki niat keluar dari organisasi (Lin \& Chen, 2004). Sehingga, dapat disimpulkan bahwa ketika seorang karyawan memiliki komitmen yang tinggi terhadap organisasinya, maka niat untuk keluar dari organisasi akan semakin kecil.

H4: Komitmen organisasional berpengaruh negatif terhadap niat untuk keluar dari organisasi.

Individu yang seringkali melakukan perbandingan dengan orang yang lebih baik atau upward comparison, cenderung fokus pada bagaimana orang lain melakukan hal yang lebih baik dari dirinya. Hal tersebut menurut Eddleston (2009) akan membuat seseorang berniat untuk keluar dari organisasi karena membandingkan dirinya dengan orang yang memiliki kinerja lebih baik juga akan meningkatkan perasaan iri dan merasa lebih inferior sehingga akan meningkatkan niat untuk keluar dari organisasi.

Sebaliknya, downward comparison akan membuat seseorang menjadi lebih nyaman 
dengan situasi yang ada saat ini. Eddleston (2009) mengemukakan bahwa ketika seseorang memiliki kecenderungan untuk downward comparison maka akan membuat orang tersebut akan memilih untuk bertahan dengan organisasi. Hal tersebut disebabkan karena downward comparison yang notabene membandingkan dengan orang yang tidak lebih baik, akan membuat seseorang merasa lebih sukses dan lebih baik sehingga akan menurunkan niatnya untuk keluar dari organisasi (Brown, Ferris, Heller, \& Keeping, 2007).

H5: Perbandingan sosial (a) Upward berpengaruh positif terhadap niat untuk keluar dari organisasi, sedangkan (b) Downward berpengaruh negatif terhadap niat untuk keluar dari organisasi.

Tingkat persaingan dalam kelompok kerja menyoroti peringkat individu dalam suatu kelompok, termasuk tingkat kesuksesan ataupun kegagalan yang pernah dialami.Tingkat persaingan dalam kelompok kerja memiliki dampak yang berbeda tergantung dari bagaimana seseorang dalam melakukan perbandingan social (Greenberg, Ashton-James, \& Ashkanasy, 2006). Eddleston (2009) mengemukakan bahwa dalam kelompok dengan tingkat persaingan yang tinggi, anggotaanggota yang ada didalamnya merasa bersaing satu sama lain. Ketika di dalam kelompok tersebut terdapat anggota yang lebih baik kinerjanya, maka anggota lain yang memiliki kecenderungan upward comparison akan merasa tidak lebih baik sehingga akan menurunkan kepuasan karir dan juga memiliki niat untuk keluar dari organisasi. Eddleston (2009) menyatakan bahwa bekerja dalam suatu kelompok dengan tingkat persaingan yang tinggi akan membuat orang atau karyawan yang memiliki kecenderungan untuk upward comparison lebih merasa tidak puas terhadap pencapaian karirnya dan juga meningkatkan niat untuk keluar dari organisasi. Begitu pula sebaliknya, bekerja di dalam suatu kelompok dengan tingkat persaingan yang tinggi antar anggotanya, justru akan membuat orang atau karyawan yang memiliki kecenderungan downward comparison merasa lebih puas dengan karirnya dan menurunkan niat untuk keluar dari organisasi (Eddleston, 2009).

H6: Tingkat persaingan dalam kelompok kerja akan (a) memperlemah pengaruh antara perbandingan sosial upward dengan kepuasan karir dan (b) akan memperkuat pengaruh antara perbandingan sosial downward dengan kepuasan karir.

H7: Tingkat persaingan dalam kelompok kerja akan (a) memperkuat pengaruh antara perbandingan sosial upward dengan niat untuk keluar dari organisasi dan (b) akan memperlemah pengaruh antara perbandingan sosial downward dengan niat untuk keluar dari organisasi.

Kerangka berpikir dalam penelitian ini adalah disajikan pada gambar 1 .

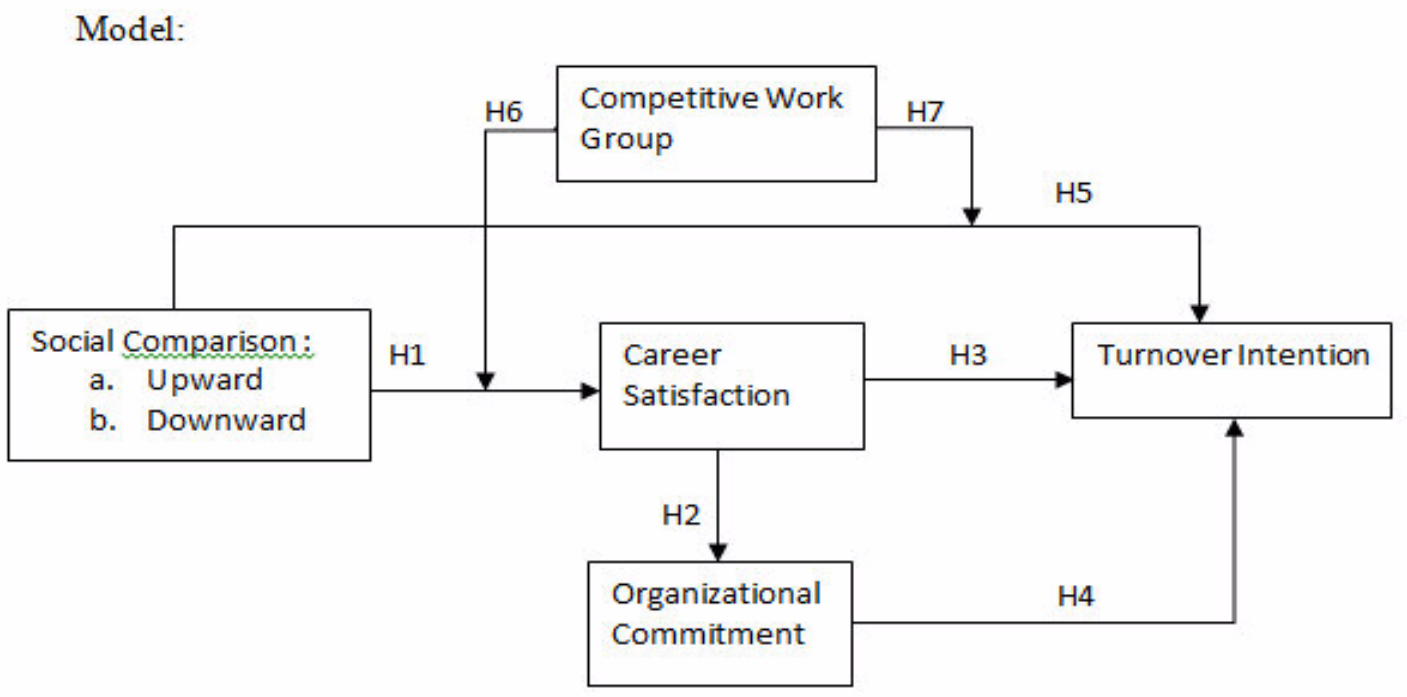

Gambar 1: Model pengaruh perbandingan sosialterhadap work attitude 


\section{METODE PENELITIAN}

Penelitian ini menggunakan pendekatan kuantitatif yang menekankan pada pengujian teori melalui pengukuran variabel penelitian dengan menggunakan prosedur statistik (Hair, Black, Babin, \& Anderson, 1995). Penelitian ini bertujuan untuk membuktikan adanya hubungan kausalitas antara variabel perceived organizational support, career satisfaction, organizational commitment, turnover inention, dan career commitment. Data yang digunakan dalam penelitian ini adalah data primer dan data sekunder.

Data primer diperoleh dari penyebaran kuisioner pada responden penelitian yaitu karyawan tetap PT Indofood Sukses Makmur Tbk Bogasari Division Surabaya. Responden penelitian merupakan karyawan tetap yang memiliki masa kerja selama minimal dua tahun sejumlah 93 karyawan. Data sekunder diperoleh dari buku, artikel, jurnal, dan dokumen perusahaan yang berhubungan dengan variabelvariabel dalam penelitian ini.variabel, pengumpulan data, terakhir melakukan analisis.

Terdapat lima variabel yang diteliti yaitu perbandingan sosial $(\mathrm{X})$, career satisfaction (Y1), organizational commitment (Y2), turnover intention (Y3), competitive work group (Z). Perbandingan sosial terdiri dari dua yaitu perbandingan sosial keatas atau upward comparison dan perbandingan sosial kebawah atau downward comparison. Perbandingan sosial keatas merupakan kecenderungan karyawan untuk membandingkan dirinya dengan orang yang lebih sukses. Sedangkan perbandingan sosial kebawah merupakan kecenderungan karyawan untuk membandingkan dirinya dengan orang lain yang lebih inferior. Menggunakan item penilaian yang diadopsi dari Eddleston (2009) terdiri dari sembilan item penilaian, diantaranya empat item penilaian perbandingan sosial keatas yaitu: 1) Kecenderungan karyawan untuk membandingkan karirnya dengan orang/karyawan lain yang lebih sukses dalam organisasi. 2) Kecenderungan karyawan untuk mengevaluasi progress karirnya dengan cara membandingkan dengan orang yang lebih sukses. 3) Motivasi karyawan untuk mencapai tingkat keberhasilan yang sama seperti karyawan lain yang lebih sukses daripada karyawan itu sendiri. 4) Karyawan menilai kesuksesan karir berdasarkan orang yang lebih sukses.
Dan lima item penilaian perbandingan sosial kebawah, yaitu: 1) Kecenderungan karyawan untuk mengevaluasi kesuksesan yang lebih dalam karirnya daripada milik orang lain. 2) Perasaan karyawan untuk merasa jauh lebih baik daripada orang lain ketika menilai prestasi karirnya. 3) Pandangan karyawan mengenai pencapaian kemajuan karirnya yang lebih baik dari karir karyawan lain di dalam organisasi. 4) Perasaan karyawan untuk bangga dengan prestasi yang sudah diraih dalam karir. 5) Perasaan karyawan mengenai karir yang telah diraih jauh lebih baik daripada pencapaian karir kartawan lain.

Penelitian ini menggunakan variabel kepuasan karir subjektif dimana kepuasan karir yang dimaksud didefinisikan sebagai penilaian atau evaluasi seseorang mengenai karirnya. Kepuasan karir diukur dengan menggunakan skala pengukuran Greenhaus et al. (1990), yang terdiri dari: 1) Tingkat kepuasan atas karier yang telah dicapai. 2) Tingkat kepuasan atas tujuan karier yang diperoleh. 3) Tingkat kepuasan atas peningkatan kinerja yang telah dicapai. 4) Tingkat kepuasan atas pengembangan kompetensi baru yang diberikan oleh perusahaan.

Dalam penelitian ini, komitmen organisasional didefinisikan sebagai hubungan yang kuat antara anggota organisasi dengan organisasi dimana anggota organisasi memiliki kepercayaan yang sangat kuat terhadap nilai serta tujuan organisasi dan berkeinginan kuat untuk mempertahankan keanggotaan dalam organisasi tersebut. Item-item pada penelitian ini menggunakan item yang diadopsi dari Lin dan Chen (2004), diantaranya: 1) Kesediaan karyawan untuk berusaha keras mencapai kesuksesan organisasi. 2) Tingkat kepedulian karyawan terhadap masa depan organisasi. 3) Perasaan bersyukur pada diri karyawan karena telah memilih organisasi tempatnya bekerja sekarang. 4) Pendapat karyawan terhadap organisasi tempatnya bekerja sekarang. 5) Perasaan bangga pada diri karyawan karena menjadi bagian dari organisasi tempatnya bekerja sekarang. 6) Kesesuaian antara nilai yang dianut oleh karyawan dengan organisasi tempatnya bekerja sekarang.

Dalam penelitian ini, turnover intention didefinisikan sebagai kekuatan niat karyawan untuk keluar dari organisasi dan mencari peluang di pekerjaan lain. Niat ini tidak bersifat 
eksplisit dan akan berakibat pada actual turnover dimana karyawan akan benar-benar keluar dari organisasi. Pengukuran menggunakan indikator yang dikembangkan oleh Mobley (1977) yang telah dimodifikasi oleh Lee dan Bruvold (2003), diantaranya adalah: 1) Niat karyawan untuk berhenti dari pekerjaan saat ini. 2) Tingkat motivasi karyawan dalam mencari pekerjaan lain. 3) Kekuatan pengaruh dari alternatif pekerjaan yang tersedia. 4) Niat karyawan untuk meninggalkan pekerjaan saat ini karena ada masalah internal dengan perusahaan.

Persaingan dalam kelompok kerja merupakan ketatnya persaingan antar anggota didalam suatu kelompok kerja. Indikator yang digunakan mengadopsi item item dari Eddleston (2009) yang terdiri dari enam item pertanyaan, diantaranya: 1) Agresifitas karyawan dalam kelompok kerja mempengaruhi keberhasilan karyawan tersebut. 2) Persaingan dalam kelompok kerja untuk mendapatkan promosi. 3) Pendapat karyawan mengenai usaha tiap karyawan dalam kelompok kerja untuk mengerahkan performa terbaik guna mencapai tujuan pekerjaan yang ditugaskan. 4) Pandangan karyawan mengenai suasana yang kompetitif dalam kelompok kerja. 5) Tingkat persaingan karyawan dalam kelompok kerja untuk mendapatkan tugas kerja yang diinginkan. 6) Dorongan dari atasan agar karyawan dapat bersaing guna mendapatkan pengakuan dan penghargaan.

Penelitian ini menyebarkan 267 kuesioner pada karyawan PT Indofood Sukses Makmur Tbk Bogasari Flour Mills Division Surabaya Perusahaan memberikan jangka waktu satu bulan bagi peneliti untuk mengumpulkan data. Ternyata, dalam kurun waktu satu bulan tersebut, terdapat 138 kuesioner yang kembali, namun hanya 127 kuesioner yang dapat digunakan. Penelitian ini menggunakan teknik analisis alternatif yakni Partial Least Square (PLS) karena PLS mampu mengakomodasi sampel yang sedikit.Maka, jumlah sampel yang digunakan dalam penelitian ini adalah 127 sampel.

\section{HASIL ANALISIS}

\section{Karakteristik Responden Berdasarkan Jenis Kelamin}

Responden berjenis kelamin laki-laki dalam penelitian ini berjumlah 75,59\% (96 orang) dan responden berjenis kelamin perempuan berjumlah $24,41 \%$ (31 orang). Sehingga, dapat disimpulkan bahwa mayoritas responden dalam penelitian ini berjenis kelamin laki-laki.

\section{Karakteristik Responden Berdasarkan Usia}

Responden yang berusia 21 hingga 25 tahun dalam penelitian ini berjumlah $3,15 \%$ (4 orang), berusia 26 hingga 30 tahun berjumlah $5,50 \%$ (7 orang), berusia 31 hingga 35 tahun berjumlah 27,55\% (35 orang), berusia 36 hingga 40 tahun berjumlah $30,70 \%$ (39 orang), dan berusia lebih dari 40 tahun berjumlah $33,27 \%$ (42 orang). Sehingga, dapat disimpulkan bahwa mayoritas responden dalam penelitian ini berusia lebih dari 40 tahun.

\section{Karakteristik Responden Berdasarkan Pen- didikan Terakhir}

Responden yang berpendidikan terakhir SMA sederajat dalam penelitian ini berjumlah $31,50 \%$ (40 orang), berpendidikan terakhir D3 berjumlah $5,51 \%$ (7 orang), berpendidikan terakhir S1 berjumlah $55,90 \%$ (71 orang), dan berpendidikan terakhir S2 berjumlah 7,09\% (9 orang). Sehingga, dapat disimpulkan bahwa mayoritas responden dalam penelitian ini berpendidikan terakhir S1.

\section{Karakteristik Responden Berdasarkan Masa Kerja}

Responden yang memiliki masa kerja selama 2 hingga 3 tahun berjumlah 5,51\% (7 orang), masa kerja selama 3 hingga 4 tahun berjumlah $6,30 \%$ ( 8 orang), dan masa kerja selama lebih dari 4 tahun berjumlah 88,19\% (112 orang). Sehingga, dapat disimpulkan bahwa mayoritas responden dalam penelitian ini telah bekerja di PT Indofood Sukses Makmur Tbk Bogasari Flour Mills Division Surabaya selama lebih dari 4 tahun.

\section{Karakteristik Responden Berdasarkan Pengalaman Kerja Sebelumnya}

Responden yang memiliki pengalaman kerja sebelumnya hanya di satu perusahaan berjumlah $63,78 \%$ (81 orang), responden yang memiliki pengalaman kerja sebelumnya di 2-4 perusahaan berjumlah $29,92 \%$ (38 orang), dan responden yang memiliki pengalaman kerja sebelumnya di lebih dari 4 perusahaan berjumlah $6,30 \%$ (8 orang). Sehingga, dapat 
disimpulkan bahwa mayoritas responden dalam penelitian ini memiliki pengalaman kerja sebelumnya hanya di satu perusahaan.

\section{Karakteristik Responden Berdasarkan Status}

Responden yang telah menikah berjumlah $88,92 \%$ (113 orang), dan responden yang belum menikah berjumlah $11,02 \%$ (14 orang). Sehingga, dapat disimpulkan bahwa mayoritas responden dalam penelitian ini telah menikah.

\section{Deskripsi Jawaban Responden Variabel Perbandingan Sosial}

Rata-rata jawaban responden terhadap variabel perbandingan sosial upward adalah sebesar 3,47 dengan kategori tinggi yang berarti bahwa responden memiliki kecenderungan yang tinggi untuk membandingkan pencapaian karirnya dengan pencapain karir milik karyawan lainnya yang lebih tinggi. Perbandingan sosial tertinggi yang dirasakan responden adalah karyawan sangat termotivasi untuk mencapai tingkat keberhasilan yang sama seperti karyawan lain yang lebih sukses. Perbandingan sosial ini memiliki nilai rata-rata sebesar 3,97. Berdasarkan tabel 4.9 diatas, dapat disimpulkan bahwa rata-rata jawaban responden terhadap variabel perbandingan sosial downward adalah sebesar 2,89 dengan kategori sedang yang berarti bahwa responden memiliki kecenderungan yang sedang untuk membandingkan pencapaian karirnya dengan pencapaian karir milik karyawan lainnya yang lebih rendah atau lebih inferior. Sedangkan perbandingan sosial terendah yang dirasakan oleh responden yakni dengan nilai rata-rata sebesar 2,67 adalah ketika responden menilai prestasi karirnya, responden tersebut sering merasa jauh lebih baik daripada karyawan lain.

\section{Deskripsi Jawaban Responden Variabel Kepuasan Karir}

Rata-rata jawaban responden mengenai variabel kepuasan kariradalah sebesar 3,15 dengan kategori sedang. Hal ini berarti bahwa responden belum merasakan kepuasan yang cukup dalam pencapain karirnya. Tingkat kepuasan tertinggi yang dirasakan responden yakni dengan nilai rata-rata sebesar 3,27 adalah tingkat kepuasan atas kemajuan yang dihasilkan dalam karirnya untuk mencapai target yang diinginkan. Sedangkan tingkat kepuasan terendah yang dirasakan responden yakni dengan nilai rata-rata sebesar 2,98 adalah tingkat kepuasan atas kesuksesan karir yang dicapai.

\section{Deskripsi Jawaban Responden Variabel Komitmen Organisasional}

Rata-rata jawaban dari responden mengenai variabel komitmen organisasionaladalah sebesar 3,86 dengan kategori tinggi. Hal ini berarti bahwa responden memiliki tingkat komitmen yang tinggi terhadap perusahaan. Tingkat komitmen tertinggi yang dimiliki responden terletak pada kesediaan karyawan untuk berjuang keras mencapai kesusksesan perusahaan. Tingkat komitmen tertinggi ini memiliki nilai rata-rata sebesar 4,30. Sedangkan tingkat komitmen terendah yang dimiliki responden terletak pada kemiripan nilai-nilai yang dianut oleh perusahaan dengan nilai-nilai yang dianut oleh responden yakni dengan nilai rata-rata sebesar 3,42.

\section{Deskripsi Jawaban Responden Variabel Niat untuk Keluar dari Organisasi}

Rata-rata jawaban dari responden terhadap variabel niat untuk keluar dari organisasiadalah sebesar 2,67 dengan kategori sedang. Hal ini berarti bahwa responden memiliki cukup keinginan untuk keluar dari perusahaan meskipun tidak terlalu banyak. Tingkat keinginan untuk berhenti dari perusahaan didominasi oleh kecenderungan karyawan untuk menerima apabila ditawari pekerjaan lain dengan paket kompensasi yang lebih baik yaitu dengan nilai rata-rata sebesar 3,30. Sedangkan indikator yang memiliki nilai rata-rata terendah yaitu kemungkinan responden untuk segera berhenti dari pekerjaannya yang sekarang, yaitu dengan nilai rata-rata sebesar 2,17.

\section{Deskripsi Jawaban Responden Variabel Persaingan dalam Kelompok Kerja}

Rata-rata jawaban responden terhadap variabel tingkat persaingan dalam kelompok kerjaadalah sebesar 3,30 dengan kategori sedang. Hal in berarti bahwa responden belum merasakan persaingan dalam kelompok kerja yang tinggi di dalam perusahaan. Tingkat persaingan dalam 
kelompok kerja tertinggi terdapat pada poin sebagian besar individu dalam kelompok kerja responden mencoba untuk mengerahkan performa terbaik satu sama lain pada tujuan pekerjaan yang ditugaskan. Poin ini memiliki nilai rata-rata sebesar 3,77. Sedangkan poin dalam kelompok kerja responden, hanya individu yang paling agresif yang akan berhasil menjadi poin dengan nilai rata-rata terendah, yakni sebesar 2,74. Hal ini berarti bahwa responden merasa tidak hanya individu yang paling agresif saja yang akan berhasil dalam kelompok kerjanya, melainkan ada aspek-aspek lainnya yang akan membuat karyawan dapat dikatan berhasil dalam kelompok kerjanya.

\section{Evaluasi Outer Model}

Pada bagian sebelumnya telah dijelaskan bahwa indikator dalam penelitian ini merupakan indikator reflektif. Evaluasi outer model untuk indikator reflektif dilihat dari nilai factor loading, composite reliability, dan validitas diskriminan.

\section{ConvergentValidity}

Berdasarkan outer loading untuk variabel perbandingan sosial upward terdiri dari USC 1, USC 2, USC 3, dan USC 4. Terdapat beberapa indikator yang harus dieliminasi karena tidak memenuhi cut off value sebesar 0.5 yaitu USC 2, USC 3 dan USC 4. Terdapat beberapa variabel lagi yang indikatornya tidak memenuhi nilai cutoff value yaitu persaingan dalam kelompok kerja yang terdiri dari CWG 1 hingga CWG 6. Dari enam indikator tersebut yang harus dieliminasi adalah indikator CWG 1, CWG 2 dan CWG 5. Begitu pula untuk variabel niat untuk keluar dari organisasi yang terdiri dari 10 indikator yang terdiri TI 1 hingga TI 10, terdapat beberapa indikator yang harus dieliminasi yaitu TI 7 dan TI 9.Untuk variabel perbandingan sosial downward yang terdiri dari DSC 1, DSC 2, DSC 3, DSC 4 dan DSC 5, ada satu indikator yang harus dieliminasi yaitu DSC 1 dan DSC 2.

Kemudian untuk variabel kepuasan karirterdiri dari CS 1, CS 2, CS 3 dan CS 4. Dari keempat indikator tersebut semuanya memenuhi cutoff value sebesar 0,5 sehingga tidak ada indikator yang dieliminasi. Hal tersebut juga berlaku untuk variabel komitmen organisasional.

\section{Composite Reliability}

Bagian kedua pada outer model adalah menguji reliabilitas dengan melihat skor composite reliability. Composite reliability menguji nilai reliabilitas antara blok indikator dari konstruk yang membentuknya. Cutoff value dari reliabilitas adalah sebesar 0,7 .

Tabel 1: Composite Reliability

\begin{tabular}{lc}
\hline & Composite Reliability \\
\hline CAREER SATIS & 0,93 \\
CWG & 0,82 \\
DSC & 0,83 \\
ORG COMIT & 0,89 \\
TI & 0,89 \\
USC & 1,00 \\
\hline SUm
\end{tabular}

Sumber: Lampiran 5 (Data primer diolah)

Berdasarkan tabel di atas dapat diketahui bahwa tidak ada nilai yang berada di bawah cutoff value. Hal tersebut mencerminkan bahwa semua variabel memenuhi standar reliabilitas.

Selain melihat skor dari composite reliability, validitas dari masing-masing nilai konstruk dapat diuji dengan average variance extracted (AVE). Konstruk dengan validitas yang dipersyaratkan nilai AVE harus di atas 0,50.

Tabel 2: Average Variance Extracted (AVE)

\begin{tabular}{lc}
\hline & AVE \\
\hline CAREER SATIS & 0,78 \\
CWG & 0,52 \\
DSC & 0,63 \\
ORG COMIT & 0.57 \\
TI & 0,50 \\
USC & 1,00 \\
\hline
\end{tabular}

Sumber: Lampiran 5 (Data primer diolah)

Berdasarkan tabel di atas dapat diketahui bahwa tidak ada nilai yang berada di bawah cutoff value. Hal tersebut mencerminkan bahwa semua variabel memenuhi standar reliabilitas.

\section{Discriminant Validity}

Discriminant validity diukur dengan menggunakan nilai cross loading. Suatu indikator dikatakan memenuhi discriminant validity jika nilai cross loadingitem pengukuran tersebut terhadap variabelnya adalah yang terbesar dibandingkan terhadap variabel lainnya. Nilai cross loading semua item pengukuran yang menyusun masing- 
masing variabel dalam penelitian ini telah memenuhi discriminant validity karena memiliki nilai cross loading terbesar untuk variabel yang dibentuknya dan tidak pada variabel yang lain. Hasil selengkapnya dapat dilihat pada Lampiran 5.

\section{Evaluasi Inner Model}

Evaluasi inner model dilakukan dengan menggunakan $R$-Square untuk variabel dependen dan uji $\mathrm{t}$ serta signifikansi dari koefisiensi parameter jalur struktural atau path coefficient yang digunakan untuk menguji hipotesis.

\section{R-Square}

Berdasarkan pengolahan data dengan PLS, dihasilkan nilai koefisien determinasi ( $R$ square) sebagai berikut:

Tabel 3: R-Square

\begin{tabular}{lc}
\hline & $\boldsymbol{R}$ Square \\
\hline CAREER SATIS & 0,21 \\
ORG COMIT & 0,06 \\
TI & 0,41 \\
\hline
\end{tabular}

Sumber: Data primer diolah

Berdasarkan tabel $R$-square di atas dapat diketahui bahwa untuk variabel kepuasan karir atau career satisfaction sebesar 0,21 , yang artinya kepuasan karir dipengaruhi oleh perbandingan sosial upward dan downward sebesar $21 \%$. Untuk variabel komitmen organisasional atau organizational commitment memiliki nilai $R$-square sebesar 0,06 , yang artinya variabel komitmen organisasional dipengaruhi oleh perbandingan sosial upward, downward dan kepuasan karir sebesar 6\%. Untuk variabel niat untuk keluar dari organsiasi atau turnover intention memiliki nilai R-square sebesar 0,41, yang artinya variabel niat untuk keluar dari organisasi dipengaruhi oleh perbandingan sosial upward, downward, kepuasan karir dan komitmen organisasional sebesar $41 \%$.

\section{Q-Square}

Dari Tabel 4.16 dapat dihitung nilai $\mathrm{Q}^{2}$ sebagai berikut:

Nilai $Q^{2}=1-(1-0,21) \times(1-0,06) \times(1-0,41)$ $=0,562$

Hasil perhitungan menunjukkan nilai $\mathrm{Q}^{2}$ sebesar 0,562 , artinya besarnya keragaman dari data penelitian yang dapat dijelaskan oleh model struktural adalah sebesar 56.2\%, sedangkan $43.8 \%$ sisanya dijelaskan oleh faktor lain di luar model struktural. Berdasarkan hasil ini, model struktural pada penelitian dapat dikatakan telah memiliki nilai predictive relevance.

\section{Goodness of Fit (GoF)}

Pengujian ini dilakukan untuk validasi model secara keseluruhan yaitu gabungan inner model dan outer model. Nilai GoF diperoleh dari average communalities index dikalikan dengan rata-rata $R$-Square.

Tabel 4: Communality

\begin{tabular}{lc}
\hline & Communality \\
\hline CS & 0,782572 \\
CWG & 0,620141 \\
DSC & 0,632493 \\
OC & 0,569508 \\
TI & 0,500000 \\
USC & 1,000000 \\
\hline Sumber: Data primer diolah \\
\multicolumn{2}{l}{ NilaiGoF $=$} \\
$\mathbf{0 , 3 9}=\sqrt{ }((\mathbf{0}, \mathbf{2 1}+\mathbf{0 , 0 6}+\mathbf{0 , 4 1}) /$ \\
$\mathbf{3}) \boldsymbol{x}(\mathbf{0 , 7 8}+\mathbf{0 , 6 3}+\mathbf{0 , 6 3}+\mathbf{0 , 5 7}+\mathbf{0 , 5 0}+$ \\
$\mathbf{1 , 0}) / \mathbf{6})$
\end{tabular}

Hasil dari perhitungan menunjukkan nilai GoF sebesar 0,39, artinya model struktural penelitian ini secara keseluruhan mengindikasikan bahwa keesesuaian model dapat dikatakan moderat. (baik $=>0,67$; moderat $=0,33-0,66$; lemah $=<0,33$ )

Path Coefficient (Menguji Hipotesis) Tabel 5 adalah hasil path coefficient berdasarkan perhitungan PLS.

Dari tabel 5 dapat disusun model struktural untuk membuktikan hipotesis penelitian sebagai berikut:

H1: Perbandingan sosial (a) upward memiliki pengaruh negatif terhadap kepuasan karir, sedangkan (b) downward memiliki pengaruh positif terhadap kepuasan karir

Berdasarkan uji hipotesis, diketahui bahwa perbandingan sosial upward tidak berpengaruh signifikan terhadap kepuasan karir. Hal ini terbukti dari nilai $t$-statistics yang kurang dari 1,64. Dengan kata lain, hipotesis 1(a) ditolak. 
Tabel 5: Path Coefficient

\begin{tabular}{lccc}
\hline & $\begin{array}{c}\text { Original } \\
\text { Sample }(\mathbf{O})\end{array}$ & $\begin{array}{c}\text { T Statistics } \\
(\mid \mathbf{O} / \text { STERR } \mid)\end{array}$ & Keterangan \\
\hline USC $\rightarrow$ CS & -0.131521 & 1.410153 & Non Signifikan \\
DSC $\rightarrow$ CS & 0.442014 & 4.247984 & Signifikan \\
CS $\rightarrow$ OC & 0.238089 & 2.433436 & Signifikan \\
$\mathrm{CS} \rightarrow$ TI & 0.028548 & 0.282627 & Non Signifikan \\
$\mathrm{OC} \rightarrow$ TI & -0.385051 & 4.262115 & Signifikan \\
$\mathrm{USC} \rightarrow$ TI & 0.204194 & 2.580422 & Signifikan \\
$\mathrm{DSC} \rightarrow$ TI & 0.020164 & 0.173671 & Non Signifikan \\
$\mathrm{USC} *$ CWG $\rightarrow$ CS & 0.046015 & 0.374765 & Non Signifikan \\
$\mathrm{DSC} *$ CWG $\rightarrow$ CS & 0.009143 & 0.042503 & Non Signifikan \\
$\mathrm{USC} *$ CWG $\rightarrow$ TI & 0.081226 & 0.831310 & Non Signifikan \\
$\mathrm{DSC} *$ CWG $\rightarrow$ TI & -0.256968 & 2.746510 & Signifikan \\
\hline
\end{tabular}

Sumber: Data primer diolah

Kemudian berdasarkan uji hipotesis, diketahui bahwa perbandingan sosial downward berpengaruh signifikan terhadap kepuasan karir. Hal ini terbukti dari nilai $t$-statistics yang lebih dari 1,64. Dengan kata lain, hipotesis 1(b) diterima.

H2: Kepuasan karir berpengaruh positif terhadap komitmen organisasional.

Berdasarkan uji hipotesis, diketahui bahwa kepuasan karir berpengaruh signifikan terhadap komitmen organisasional. Hal ini terbukti dari nilai $t$-statistics yang lebih dari 1,64. Dengan kata lain, hipotesis 2 diterima.

H3: Kepuasan karir berpengaruh negatif terhadap niat untuk keluar dari organisasi.

Berdasarkan uji hipotesis, diketahui bahwa kepuasan karir tidak berpengaruh signifikan terhadap niat untuk keluar dari organisasi. Hal ini terbukti dari nilai $t$-statistics yang kurang dari 1,64. Dengan kata lain, hipotesis 3 ditolak.

H4: Komitmen organisasional berpengaruh negatif terhadap niat untuk keluar dari organisasi.

Berdasarkan uji hipotesis, diketahui bahwa komitmen organisasional berpengaruh signifikan terhadap niat untuk keluar dari organisasi. Hal ini terbukti dari nilai t-statistics yang lebih dari 1,64. Dengan kata lain, hipotesis 4 diterima.

H5: Perbandingan sosial (a) Upward berpengaruh positif terhadap niat untuk keluar dari organisasi, sedangkan (b) Downward berpengaruh negatif terhadap niat untuk keluar dari organisasi.
Berdasarkan uji hipotesis, diketahui bahwa perbandingan sosial upward berpengaruh signifikan terhadap niat untuk keluar dari organisasi. Hal ini terbukti dari nilai t-statistics yang lebih dari 1,64. Dengan kata lain, hipotesis 5(a) diterima.

Kemudian berdasarkan uji hipotesis, diketahui bahwa perbandingan sosial downward tidak berpengaruh signifikan terhadap niat untuk keluar dari organisasi. Hal ini terbukti dari nilai t-statistics yang kurang dari 1,64. Dengan kata lain, hipotesis 5(b) ditolak.

H6: Tingkat persaingan dalam kelompok kerja akan (a) memperlemah pengaruh antara perbandingan sosial upward dengan kepuasan karir dan (b) akan memperkuat pengaruh antara perbandingan sosial downward dengan kepuasan karir.

Berdasarkan uji hipotesis, diketahui bahwa tingkat persaingan dalam kelompok kerja atau competitiveness work group tidak memiliki efek moderasi yang signifikan terhadap hubungan antara perbandingan sosial upward dengan kepuasan karir karena nilai t-statistics yang kurang dari 1,64. Maka dari itu hipotesis 6(a) ditolak.

Berdasarkan uji hipotesis, diketahui bahwa tingkat persaingan dalam kelompok kerja atau competitiveness work group tidak memiliki efek moderasi yang signifikan terhadap hubungan antara perbandingan sosial downward dengan kepuasan karir karena nilai $\mathrm{t}$-statistics yang kurang dari 1,64. Maka dari itu hipotesis 6(b) ditolak.

H7: Tingkat persaingan dalam kelompok kerja akan (a) memperkuat pengaruh antara perbandingan sosial upward dengan niat 
untuk keluar dari organisasi dan (b) akan memperlemah pengaruh antara perbandingan sosial downward dengan niat untuk keluar dari organisasi.

Berdasarkan uji hipotesis, diketahui bahwa tingkat persaingan dalam kelompok kerja atau competitive work group tidak memiliki efek moderasi yang signifikan terhadap hubungan antara perbandingan sosial upward dengan niat untuk keluar dari organisasi karena nilai t-statistics yang kurang dari 1,64. Maka dari itu hipotesis 7(a) ditolak.

Berdasarkan uji hipotesis, diketahui bahwa tingkat persaingan dalam kelompok kerja atau competitive work group tidak memiliki efek moderasi yang signifikan terhadap hubungan antara perbandingan sosial downward dengan niat untuk keluar dari organisasi karena nilai t-statistics yang lebih dari 1,64. Maka dari itu hipotesis 7(b) diterima.

\section{DISKUSI DAN KESIMPULAN}

Berdasarkan hasil pengujian hipotesis, terdapat lima hipotesis yang diterima, dan empat hipotesis yang tidak diterima. Lima hipotesis yang diterima tersebut adalah: 1) Pengaruh Perbandingan sosial Downward terhadap Kepuasan Karir. 2) Pengaruh Kepuasan Karir terhadap Komitmen Organisasional. 3) Pengaruh Komitmen Organisasional terhadap Niat untuk Keluar dari Organisasi. 4) Pengaruh Perbandingan Sosial Upward terhadap Niat untuk Keluar dari Organisasi. 5) Tingkat Persaingan dalam Kelompok Kerja akan Memperlemah Pengaruh antara Perbandingan Sosial Downward dengan Niat untuk Keluar dari Organisasi.

Kelima hipotesis diatas mengkonfirmasi dugaan peneliti dan memberikan kesimpulan bahwa karyawan PT Indofood Sukses Makmur Tbk Bogasari Division Surabaya merasa puas dengan karir yang dicapai secara individual setelah membandingkan pencapaian karirnya dengan orang yang lebih inferior. Kepuasan yang dicapai tersebut kemudian membuat karyawan semakin berkomitmen pada organisasi dan bekerja keras demi mencapai tujuan organisasi, sehingga karyawan tidak mudah untuk berniat keluar dari organisasi. Serta tingkat persaingan dalam kelompok kerja akan memperlemah pengaruh antara perbandingan sosial downward dengan niat karyawan untuk keluar dari organisasi. Sedangkan berikut ini merupakan empat hipotesis yang tidak diterima dalam penelitian ini beserta pembahasannya:

\section{Perbandingan Sosial (A) Upward Terhadap Kepuasan Karir}

Dalam penelitian ini mayoritas responden adalah karyawan yang berusia lebih dari 40 tahun. Berdasarkan hasil penelitian yang dilakukan oleh Buunk (2007) ditemukan bahwa terdapat perbedaan kecenderungan perbandingan sosial yang dilakukan oleh karyawan yang berusia muda dan lebih dari 40 tahun. Dalam penelitian tersebut ditemukan bahwa karyawan yang berusia muda akan lebih cenderung untuk membandingkan dirinya dengan seseorang yang lebih baik dari dirinya atau memiliki upward comparison (Seibert \& Kraimer, 2001). Sebaliknya, karyawan yang berusia lebih dari 40 tahun justru cenderung untuk lebih membandingkan dirinya dengan orang yang lebih inferior. Hal tersebut terkait dengan kenyamanan dan loyalitas kerja dari karyawan, khususnya karyawan PT. Indofood Sukses Makmur Tbk Bogasari Flour Mills Division Surabaya.Maka dari itu dalam penelitian ini yang notabene mayoritas respondennya adalah karyawan yang berusia lanjut atau lebih dari 40 tahun, justru ditemukan bahwa upward comparison tidak berpengaruh signifikan terhadap kepuasan karir.

Mengacu dari hasil penelitian yang dilakukan oleh Buunk (2007) bahwa karyawan yang berusia lanjut atau dalam penelitian ini adalah karyawan PT. Indofood Sukses Makmur Tbk Bogasari Flour Mills Division Surabaya yang berusia lebih dari 40 tahun ini cenderung untuk membandingkan dirinya dengan orang yang lebih inferior sehingga hal tersebut akan membuat karyawan tersebut lebih nyaman dan puas terhadap karirnya saat ini. Hasil dari penelitian kali ini sesuai dengan apa yang dikatakan oleh Eddleston (2009) bahwa seseorang dengan kecenderungan untuk membandingkan dengan orang lain yang lebih inferior, maka hal tersebut akan meningkatkan self esteem yang dimiliki sehingga akan merasa puas terhadap karirnya dan cenderung lebih loyalterhadap perusahaannya. 
Kepuasan Karir Terhadap Niat Untuk Keluar Dari Organisasi

Berdasarkan hasil dalam penelitian ini, kepuasan karir terbukti memiliki pengaruh positif yang tidak signifikan terhadap niat untuk keluar dari organisasi.Hasil ini berlawanan dengan hipotesis yang menyatakan bahwa hubungan kedua variabel memiliki pengaruh negatif.Namun demikian, pengaruh positif tersebut juga tidak signifikan.

Seperti yang telah dijelaskan sebelumnya bahwa responden dalam penelitian ini mayoritas adalah karyawan dengan usia 40 tahun keatas. Burt dalam As'ad (2003) menyatakan bahwa semakin tua usia karyawan, toleransi karyawan terhadap ketidakpuasan akan semakin meningkat. Sehingga walaupun karyawan PT Indofood Sukses Makmur Tbk Bogasari Flour Mills Division Surabaya tidak cukup puas dengan karirnya di perusahaan, karyawan lebih mampu menoleransi hal tersebut sehingga tidak sampai membuat karyawan berniat untuk meninggalkan perusahaan (Hurlock, 2002). Sebagai tambahan, mayoritas masa kerja responden dalam penelitian ini adalah minimal empat tahun. Igbaria dan Greenhaus (1992) menyatakan bahwa karyawan dengan usia lebih tua dan masa kerja lebih lama memiliki niat untuk keluar dari organisasi lebih rendah.

\section{Perbandingan Sosial Downward Berpenga- ruh Negatif Terhadap Niat Untuk Keluar Dari Organisasi}

Berdasarkan hasil dari penelitian ini diketahui bahwa perbandingan sosial keatas atau upward comparison karyawan PT Indofood Sukses Makmur Bogasari Flour Mills Division Surabaya berpengaruh positif secara signifikan terhadap niat untuk keluar dari organisasi. Hal ini berarti bahwa semakin tinggi tingkatan karyawan PT Indofood Sukses Makmur Bogasari Flour Mills Division Surabaya melakukan perbandingan sosial keatas, maka akan semakin tinggi pula kecenderungan karyawan untuk keluar dari organisasi. Hasil ini sesuai dengan penelitian yang dilakukakan oleh Eddleston (2009) yang menyatakan bahwa salah satu hal yang mendukung seorang karyawan memiliki niat untuk keluar dari organisasi adalahkarena membandingkan dirinya dengan karyawan yang memiliki kinerja lebih baik, sehingga akan meningkatkan perasaan iri dalam dirinya dan merasa lebih inferior dari karyawan tersebut, sehingga akan meningkatkan niat untuk keluar dari organisasi.

\section{Tingkat Persaingan Dalam Kelompok Kerja Akan (A) Memperlemah Pengaruh Antara Perbandingan Sosial Upward Dengan Kepuasan Karir Dan (B) Akan Memperkuat Pengaruh Antara Perbandingan Sosial Downward Dengan Kepuasan Karir}

Dalam penelitian ini tidak ada efek moderasi yang diciptakan oleh tingkat persaingan dalam kelompok kerja atau competitiveness work group pada hubungan antara perbandingan sosial upward terhadap kepuasan karir karyawan PT Indofood Sukses Makmur Tbk Bogasari Flour Mills Division Surabaya. Berdasarkan hasil penelitian yang dilakukan oleh Buunk dan Gibbons (2007) ditemukan bahwa terdapat perbedaan kecenderungan perbandingan sosial yang dilakukan oleh karyawan yang berusia muda dan lebih dari 40 tahun. Mayoritas responden dalam penelitian ini, yaitu karyawan PT Indofood Sukses Makmur Tbk Bogasari Flour Mills Division Surabaya yang berusia lebih dari 40 tahun beranggapan bahwa faktor kenyamanan dalam bekerja dan loyalitas terhadap perusahaan merupakan hal yang lebih penting daripada persaingan antar karyawan dalam kelompok kerja untuk menunjukkan siapa yang terbaik dalam perusahaan.

Sama halnya dengan hubungan perbandingan sosial upward dengan niat untuk keluar dari organisasi, tidak ada efek moderasi yang diciptakan oleh tingkat persaingan dalam kelompok kerja pada hubungan antara perbandingan sosial kebawah atau downward comparison dengan niat untuk keluar dari organisasi.Hal tersebut ditunjang dengan jawaban responden tentang variabel persaingan dalam kelompok kerja bahwa responden belum terlalu merasakan adanya persaingan dalam kelompok kerja di perusahaan sehingga tidak ditemukan dampak signifikan dari persaingan kelompok kerja yang dapat memperkuat atau memperlemah hubungan antara perbandingan sosial upward dan downward terhadap kepuasan karir karyawan PT Indofood Sukses Makmur Tbk Bogasari Flour Mills Division Surabaya. Hal ini sesuai dengan hasil penelitian dari Buunk (2007) bahwa untuk karyawan yang berusia lebih dari 40 tahun dan memiliki masa 
kerja yang tinggi, karyawan tersebut akan mengutamakan kenyamanan dalam bekerja sehingga tidak memikirkan persainganpersaingan yang ada dalam perusahaan.

\section{Tingkat Persaingan Dalam Kelompok Kerja Akan Memperkuat Pengaruh Antara Perbandingan Sosial Upward Dengan Niat Untuk Keluar Dari Organisasi}

Persaingan dalam kelompok kerja tersebut tidak memiliki peranan yang signifikan terhadap karyawan yang melakukan perbandingan sosial upward dengan niat untuk keluar dari organisasi karyawan tersebut. Hal ini disebabkan karena mayoritas usia responden yang lebih dari 40 tahun, memiliki masa kerja yang lama di perusahaan tersebut (dalam penelitian ini lebih dari 4 tahun), dan mayoritas sudah menikah seperti yang ada ditemukan oleh Buunk dan Gibbons (2007). Untuk karyawan tersebut, loyalitas dalam perusahaan merupakan hal yang sangat penting karena bila karyawan tersebut keluar dari perusahaan, belum tentu akan langsung mendapatkan pekerjaan dan karir yang lebih bagus dari yang telah dimiliki sekarang. Maka karyawan tersebut akan lebih memilih untuk setia dalam perusahaan dan karir yang telah dimiliki sekarang, sehingga mereka akan lebih menekankan pada loyalitas mereka dalam perusahaan sehingga akan mengurangi niat mereka untuk keluar dari organisasi, bahkan niat tersebut akan semakin berkurang ketika karyawan tersebut ditempatkan di persaingan dalam kelompok kerja karena mereka akan lebih merasakan kenyamanan bekerja yang meningkat dalam perusahaan. Hal tersebut ditunjang dengan jawaban responden tentang variabel persaingan dalam kelompok kerja bahwa responden belum terlalu merasakan adanya persaingan dalam kelompok kerja di PT Indofood Sukses Makmur Tbk Bogasari Flour Mills Division Surabaya.

\section{DAFTAR PUSTAKA}

As'ad, Moh. 2003. Psikologi Industri. Yogyakarta: Galia Indonesia.

Barnett, BR., L. Bradley. 2007. The impact of organizational support for career development on career satisfaction. Career Development International. 12(7), 617-636.
Brown, D.J., Ferris, D.L., Heller, D., \& Keeping, L.M. 2007 . Antecedents and consequences of the frequency of upward and downward social comparisons at work. Organizational Behavior and Human Decision Processes. 102, 59-75.

Buchana, B.H. 1994. Building organization commitment: the socialization of managers in work, organizations. Administrative Science Quarterly, Vol. 19, pp. 17-22.

Buunk, A.P. dan Gibbons, F.X. 2007. Social comparison: the end of a theory and the emergence of a field. Organizational Behavior and Human Decision Processes. 102, 3-21.

Capelli, P. 2000. Managing without commitment. Organizational Dynamics, Vol. 28 No. 4, pp. 11-24.

Chen, Z. X., dan Fransesco, A. M. 2003. The relationship between the three components of commitment and employee performance in China. Journal of Vocational Behavior, 62, p. 490-510.

Dyke, L.S. dan Duxbury, L.E. 2011, The implications of subjective career success. Journal for Labour Market Research, 43, 219-229.

Eddleston, K.A. 2009. The effects of social comparison on managerial career satisfaction and turnover intentions. Career Development International. 14, 1. p 87-110.

Greenberg, J., Ashton-James, C.E., \& Ashkanasy, N.M. 2006. Social comparisons processes in organizations. Organizational Behavior and Human Decision Processes. 102, 22-41.

Greenhaus, J.H. et al. 1990. Effects of race on organizational experiences, job performance evaluations, and career outcomes. Academy of Management Journal, Vol.33, pp. 64-86.

Hair, J. F., Black, W.C., Babin, B.J., \& Anderson, R.E. 1995. Multivariate Data Analysis. New York: Macmillan. 
Heslin, P.A. 2005. Conceptualizing and evaluating career success. Journal of Organizational Behavior, 26 (2): 11336.

Hurlock, E. B. 2002. Psikologi Perkembangan : Suatu Pendekatan Sepanjang Rentang Kehidupan. Surabaya: Erlangga.

Igbaria, M., dan J.H. Greenhaus. 1992. Determinants of mis employees' turnover intentions: a structural equation model. Communications of The ACM, Vol. 35, No.2.

Kim, YG. 2012. Travel agency employees' career commitment and turnover intention during the recent global economic crisis. The Service Industries Journal. 32(8), 1247-1264.

Lee, C.H.,dan Bruvold, N.T. 2003. Creating value for employees: investment in employee development. International Journal of Human Resource Management, Vol.14, No. 6, pp. 981-1000.

Lin, CP., M.F Chen. 2004. Career commitment as a moderator of the relationships among procedural justice, perceived organizational support, organizational commitment, and turnover intentions. Asia Pacific Management Review. 9(3), 519-538.

Mobley, W.H. 1977. Intermediate linkages in the relationship between job satisfaction and employee turnover. Journal of Applied Psychology.62,2.p 237-240.

Portalhr. 2014. 78,3\% Karyawan Tidak Punya Jenjang Karir yang Jelas, (Online), (http://www.portalhr.com/berita/783karyawan-tidak-punya-jenjang-kariryang-jelas/, diakses pada tanggal 9 April 2014).

Seibert, S.E., dan M.L. Kraimer. 2001. The five-factor model of personality and career success. Journal of Vocational Behavior, 58.p 1-21.

Wright, T. A., dan Douglass G. Bonett. 2007. Job satisfaction and psychological well-being as nonadditive predictors of workplace turnover. Journal of Management, 33:141. 